\title{
Never Together: \\ Black and White People in the Postwar Economic Era
}

\author{
Peter Temin ${ }^{1}$
}

\section{Working Paper No. 128}

July 8, 2020

\begin{abstract}
This paper recounts American economic history for 60 years after World War II. The unusual part of this paper is that it focuses on not only the conventional tale, but also recounts what whites did to and for Blacks over this period. It starts from the unhappy experience of a Black American soldier, goes through the prosperity that followed the war and ends with the various changes that happened to the economy after 1970. The Civil Rights Movement is in the middle, and it gave rise to more Black education before racial segregation destroyed their gains. Some Blacks graduated from college and became a Black Elite. Obama's election showed that the Black Elite could interact with relative equality with educated whites.
\end{abstract}

JEL Codes: J15, N11, N12, K31

Keywords: African Americans, Negroes, slavery, Jim Crow, Great Migration, World War II, Supreme Court.

\footnotetext{
${ }^{1}$ Elisha Gray II Professor Emeritus at MIT. Contact: ptemin@mit.edu. This paper is adapted from a book in process that covers most of American economic history. I thank INET for financial support and Trevon Logan and Thomas Ferguson for comments on the underlying manuscript.
} 


\section{https://doi.org/10.36687/inetwp128}

I begin this discussion of the interaction of Black and white people in the postwar years with Isaac Woodard's tragic story, beginning with the song Woody Guthrie sang wrote about him. Woodard was a veteran of a segregated Army unit in the Pacific during the Second World War where he had earned several awards for his service.

My name is Isaac Woodard, my tale I'll tell you;

I'm sure it'll sound so terrible you might not think it true;

I joined up with the Army, they sent me overseas;

Through the battles of New Guinea and in the Philippines.

On the 13th day of February 1946

They sent me to Atlanta and I got my discharge pin;

I caught the bus for Winslow, going to meet my wife,

Then we were coming to New York City to visit my parents both.

About an hour out of Atlanta, the sun was going down,

We stopped the bus at a drugstore in a little country town;

I walked up to the driver and I looked him in the eye,

"I'd like to go to the washroom, if you think we got time."

The driver started cursing, and then he hollered, "No!"

So, then I cussed right back at him, and really got him told.

He said, "If you will hurry, I guess I'll take the time!"

It was in a few short minutes we was rolling down the line.

We rolled for thirty minutes, I watched the shacks and trees,

I thought of my wife in Winsboro waiting there for me.

In Aiken, South Carolina, the driver he jumped out;

He came back with a policeman to take me off the bus.

"Listen, Mr. Policeman," I started to explain,

"I did not cause no trouble, and I did not raise no cain."

He hit me with his billy, he cursed me up and down,

"Shut up, you black bastard"; and he walked me down in town.

As we walked along the sidewalk, my right arm he did twist;

I knew he wanted me to fight back, but I never did resist;

"Have you your Army discharge?" I told him, yes, I had;

He pasted me with his loaded stick down across my head. 
I grabbed his stick and we had a little run, and had a little wrastle;

When another cop run up with a gun and jumped into the battle;

"If you don't drop that sap, black boy, it's me that's dropping you."

So I figured to drop that loaded sap was the best thing I could do.

They beat me about the head and face and left a bloody trail

All down along the sidewalk to the iron door of the jail;

He knocked me down upon the ground and he poked me in the eyes;

When I woke up next morning, I found my eyes were blind.

They drug me to the courtroom, and I could not see the judge;

He fined me fifty dollars for raising all the fuss;

The doctor finally got there but it took him two whole days;

He handed me some drops and salve and told me to treat myself.

It's now you've heard my story, there's one thing I can't see,

How you could treat a human like they have treated me;

I thought I fought on the islands to get rid of their kind;

But I can see the fight lots plainer now that I am blind. Guthrie (ND).

The National Association for the Advancement of Colored People (NAACP) and others convinced the government to sue Police Officer Shull, who had blinded Woodard. A prominent forensic pathologist concluded that the crush of both Woodard's eyes required a penetrating injury in each eye, consistent with Woodard's claim that Shull drove the handle end of his blackjack into each eye. The trial was held in South Carolina before an all-white jury in late 1946, which swiftly decided Shull was not guilty. Judge Waring, who was the judge in Woodard's trial, was upset enough to begin reading about the condition of Blacks in the United States.

President Truman was very interested in civil rights for America's African Americans, and he appointed a President's Committee on Civil Rights at the end of 1946 that issued its report in October 1947. The report, entitled "To Secure These Rights," focused on four rights: to safety and the security of the individual, to citizenship and its privileges, to freedom of conscience and expression, and to equal opportunity. They discussed the pattern of lynching and reported on several cases of police brutality against Blacks, like the violence against Isaac Woodard.

The report also condemned segregated schools, restrictive racial covenants, discrimination in federal services and racial discrimination in Washington, DC. The harshest criticism pinpointed federal government discrimination against Blacks. The study cited the 1896 Supreme Court decision in the case of Plessy v. Ferguson as a prime example of this fault and objected that the decision was incompatible with the $14^{\text {th }}$ Amendment. The report made many recommendations 
for federal government actions to secure the rights they listed for all American citizens (Gergel, 2019, 145-49).

Many of Truman's advisors urged him to moderate his support for civil rights, but Truman stayed with his program and made civil rights central to many of his speeches. For example, he received a letter from a Missouri man who had served with him in World War I that urged Truman to moderate his view to be reelected. Truman responded in a private letter that was released only after Truman's death. Truman said he was not asking for equality, but equality of opportunity. He cited the treatment of Isaac Woodard and said, "I can't approve of such goings on and I shall never approve it, I am going to try and remedy it and if that ends up in my failure to be reelected, that failure will be in a good cause."

Truman proclaimed two executive orders in July 1948, that implemented some of the committee's recommendations and made his position clear. The most often cited executive order outlawed racial segregation in the military and mandated equality in America's armed forces. The other executive order prohibited discrimination in federal employment-extending the prohibition on segregation in civilian parts of the federal government. Despite all of these strong statements and actions, President Truman won reelection in 1948 in an upset victory over the governor of New York, Thomas Dewey.

The military resisted implementation of Truman's desegregation order. Truman therefore appointed a committee to review and approve the desegregation plans of each branch of the military. Truman reiterated in 1949 that his order was desegregation and he was using his power as commander in chief to make these changes. The committee rapidly agreed to plans by the navy and air force, but the army resisted Truman's order. They said Blacks were not suited for combat but rather for manual labor. This traditional Southern argument lost its force as the other branches agreed to desegregate, and the army fell into line and agreed to implement Truman's order (Gergel, 2019, 155-63).

Judge Waring entered this story in 1951 after reading up on the position of Blacks in the United States and becoming a vocal advocate of civil rights. He was part of a three-judge panel in a suit to protest inferior Black schools in South Carolina in Briggs v. Elliott, 342 U.S. 350 (1952). He recommended to the plaintiffs that the case should be expanded from an equalization case into a desegregation case. Instead of asking for enforcement of the separate but equal doctrine by bringing the Black schools up to equality with the white schools, the plaintiffs asked that school segregation should be declared unconstitutional.

Judge Waring wrote a minority opinion for the panel that cited research by Kenneth and Mamie Clark that showed separate schools have "detrimental effects on the personality development of the Negro child." The Clarks had done their standard experiment with South Carolina children. They used four dolls, identical except for color, to test children's racial perceptions. Their subjects, Black and white children between the ages of three to seven, were asked to identify both the race 
of the dolls and which color doll they prefer. A majority of the children preferred the white doll and assigned positive characteristics to it. The Clarks concluded that "prejudice, discrimination, and segregation" created a feeling of inferiority among African-American children and damaged their self-esteem. Kenneth Clark testified, "The conclusion which I was forced to reach was that these children of Clarendon County, like other human beings subjected to an obviously inferior status in society in which they live, have been definitely harmed in the development of their personalities" and such injuries were "enduring." Waring used Clark's evidence in his dissent and argued "Segregation is per se inequality (Briggs v. Elliott, Transcript of Record, 83-90)."

The Supreme Court bundled several local cases into Brown v. Board of Education of Topeka, 347 U.S. 483 (1954). This was the first large decision of Chief Justice Warren, and it ruled unanimously that Plessy v. Ferguson was unconstitutional. The decision cited Waring's dissent and used Kenneth Clark's social science as evidence for its conclusion. It followed Truman's executive orders abolishing segregation in the military and federal offices, and it was the final act of the blinding of Isaac Woodard.

Brown v. Board of Education was a departure from the Supreme Court's usual decisions supporting the positions of the wealthy and powerful. This decision opposed Plessy v. Ferguson and the various decisions the Supreme Court made in the 1880s nullifying the $14^{\text {th }}$ Amendment. It would become an isolated decision when the Supreme Court reverted to its usual stance in the early $21^{\text {st }}$ century.

There are three implications of this story. First, Jim Crow laws and attitude continued throughout the first half of the $20^{\text {th }}$ century and were in full evidence after peace returned. Jim Crow was not an aberration, but a critical part of Southern Society. The Great Migration in progress at this time was expanding the reach of this attitude to a national ethos as economic recovery continued. Second, the Supreme Court resisted this view in a decision that reflected the will of the people rather than the aims of the rich and powerful. This turned out to be a temporary shift in Supreme Court decisions despite the wishes of many people that it would be a permanent change. Third, President Truman started the Civil Rights Movements with his desegregation orders a decade before President Johnson proposed his more famous extensions of Brown v. Board of Education.

Like the $14^{\text {th }}$ Amendment, Brown was honored in the breach as white legislatures could not bring themselves to provide equal resources for Black students whose parents did not vote. The issue in Brown, however, was not the inequality of schools, but the constitutionality of separation. In a pattern that would be repeated in the north as the Great Migration continued, whites in the South moved their children's schools into suburban areas where Blacks were not welcome. As seen so many times already, whites found ways to nullify the effects of national decisions by preserving the letter of the court's decision while ignoring the spirit and aspiration of the decision (Margo, 1990). 
The Second World War ended better than its predecessor, suggesting that the victors had learned from history. Instead of the rancor that ended the First World War, there was a feeling of cooperation that led to a generation of economic growth in America and Europe. While many contemporaries thought that a new era was beginning, a lot of the European postwar growth was recovery from the damage and lost opportunities during the war. Les Trente Gloriouse, as this period was known in and out of France, was symbolized by international cooperation expressed in the nascent United Nations and the Bretton Woods system for international payments. The United States was not where fighting took place during the war, and its products were much in European demand during the period of reconstruction. A persistent dollar shortage was the result of this high demand (Temin, 2002; Neal, 2015).

Instead of an armistice, the United States insisted on unconditional surrender. The lack of communication between Hitler in his bunker and the Allies entering Berlin in 1945 contrasted sharply with the conversation between Grant and Lee at Appomattox in 1865. Instead of supporting a punitive treaty like the 1919 Treaty of Versailles, the United States stepped up to help rebuild Western Europe. And the United Nations, headquartered in New York, replaced the moribund League of Nations in Geneva.

The New Deal did not extend much to Blacks, and Social Security did not extend to most Blacks for the first quarter-century of its existence. The 1944 GI Bill provided educational benefits for veterans of the Second World War, but it did not guarantee admission to colleges. Few Blacks were admitted to Northern colleges and universities due to bad Southern schooling. Blacks therefore applied to Southern Black colleges - being excluded from Southern white collegeswhich did not have capacity to take them. Southern states refused to expand the facilities of Black colleges, particularly dormitories, and much of the Black demand for college education went nowhere. Black veterans also were not helped to get good jobs by the GI Bill. Local employment agencies funded by the bill directed them to traditional Black jobs, ignoring learning that had occurred in the army, and banks often refused loans to Black veterans who lacked capital or credit ratings and lived in undesirable neighborhoods.

The GI Bill appeared to offer eligible African Americans more benefits and opportunities than they could have imagined in 1940. But the administration of the bill discriminated sharply against them to the point of mocking them for believing the promise of equal treatment. It significantly curtailed the bill's egalitarian promise and widened the country's large racial gap. Yet again, policies designed to transfer and create wealth and economic opportunities were restricted to whites by design (Katznelson, 2005, chap. 5).

African Americans responded to the pressure on them in Southern states by moving north and west in the Great Migration. Black workers continued to move out of the oppressive South to better their lives and employment opportunities, but this move was not always successful, and Blacks lost ground relative to whites after the Second World War. The national unemployment rate for 
Blacks and whites was the same in 1930; the Black rate was double that of whites in 1965. The unemployment rate for Black teenage boys went from being slightly less than whites in 1948 to being almost twice as high in 1965. Employers did not consider the Black migrants to the North to be full substitutes of their white employees, so the migrants competed largely with earlier Black migrants. While the migrants greatly increased their incomes, this was partly at the expense of earlier migrants.

This was true for several reasons. Most migrating Blacks had poor education and limited skills. White employers continued in the time-honored practice of only hiring the new Black migrants to the worst jobs. This set up competition between new and old migrants and kept their wages down. This not to deny the gains that the new migrants enjoyed, but to explain why Black wages failed to rise relative to white wages. Whites also left cities for the suburbs. For every Black entering a northern city, almost three whites left. They left both because they did not want Black neighbors and because they expected that more Blacks would lead to higher taxes to provide public goods (Boustan, 2017).

The lower incomes and employment rate of Blacks reduced their accumulation of wealth. Senator Elizabeth Warren summarized the effects of Black exclusions: "Entire legal structures were created to prevent African Americans from building economic security through home ownership. Legally enforced segregation. Restrictive deeds. Redlining. Land contracts. Coming out of the Great Depression, America built a middle class, but systematic discrimination kept most AfricanAmerican families from being part of it (quoted in Temin, 2017, 53)."

Thus began a generation of prosperity and economic growth for whites, where the United States dominated the world economy. It was one big wave of United States growth in the words of Robert Gordon. The innovations that produced this growth occurred earlier, but growth was diverted into the Second Thirty Years War in the first part of this long wave, and the results reached the population at large in the years following 1945.

Four groups of inventions generated this big wave. The first was electricity. Electric light extended the length of the day that could be used for all sorts of work and play. It was introduced in the $1890 \mathrm{~s}$ and extended to many prosperous urban households, but electricity did not revolutionize production until after the wars. Factories needed to be drastically reorganized to benefit from electric motors, and only after war production ceased could new factories be built under the new plans.

The second innovation was the internal combustion engine, which made personal and public transport far more attainable. After Ford's introduction of the Model T before the First World War and the Model A after the war, the initial use of the internal combustion was limited to tanks and other military vehicles. Trucks were introduced in farms during the Depression, but their spread 
was limited by low agricultural prices. As with electricity, the full impact of this innovation blossomed after 1945 .

The third group of innovations was the use of petrochemicals to produce plastics and antibiotics. As petroleum replaced other sources of power for transport, that is, as gas-guzzling cars replaced trains, refiners discovered that petrochemicals could be used for other purposes. Plastics had become popular enough for the college graduate in The Graduate, a 1967 movie, to be told to remember only one word to be successful: plastics. Antibiotics, first discovered between the world wars, became generally available only in the 1950s, prolonging the life of children and adults. After new regulations in 1938, most of the new drugs were available by prescription only. The growth of large pharmaceutical companies and hospitals was not the result of technology alone, but of the interaction of new discoveries and government policies.

Finally, the fourth innovation was in communication and information. Radios were ubiquitous in the interwar years. TV appeared late in that period, but only diffused after the war ended. They filled a void in earlier life where nothing existed and had as great an impact on daily life as the spread of electricity itself (David, 1994; Gordon, 2000, 2016).

The second and third of these innovations - cars and gas to fuel them-also started the climate change that began to rise around 1970. Many reasons have been given for the slowdown after that time, and global warming will be discussed more fully in the next chapter. It is necessary here to remind ourselves that these innovations were not simply gifts to American society.

White flight was encouraged by the third innovation of the big wave, the advent of the automobile age. Cars, and particular farm trucks, had made their appearance before the war, but the Great Depression and then war had delayed their spread. President Eisenhower signed the Federal Aid Highway Act in 1956 and set in motion a construction project that is inconceivable today. A national plan of highways was constructed with state and federal cooperation, financed by government bonds. Suburbs and suburban living became the symbol of postwar prosperity.

Blacks were omitted from this great remodeling of American city living. As Blacks continued to move north in the Great Migration, they did not have the resources to buy suburban houses. Banks would not lend to them, as they did to whites, to allow them to accumulate real-estate capital. Redlining and job restrictions combined to confine Blacks to the cities being vacated by whites as Senator Warren said. And rural segregation also rose. There was less and less personal contact between the races as time went on.

While this pattern rose from restrictions, they also were the results of the Great Migration. Like other migrations, many international ones, Blacks from the South moved to join Blacks in the North. Family members clearly joined relatives, and unrelated migrants felt more at home with people who were similar to those back home. Migrants were more educated than the group they left, but less educated than the group they joined. The former comparison suggests that more 
educated Blacks were motivated to seek better jobs in the North. The latter comparison is a result of the poor state of Black education in the South (Tolnay, 2003; Margo, 1990).

Isabel Wilkerson described the diversity of migrants who left the South in the Great Migration through an intense examination of the varied lives of a few of them. We can note their variety here, but a full appreciation of their individuality requires reading the details in Wilkerson's fine book. Ida Mae Gladney, a sharecropper's wife from MS, lived in Chicago for the next fifty years. Her life revolved around family, church and work as it would have in MS, but the context was different. She lived a working-class life in the North and eventually had six grandchildren. George Starling moved North, but he had an unhappy wife and two children that ran into legal troubles as teenagers while Starling and his wife were working hard to raise them. Starling did not progress far up the labor ladder in the North, but he was not bitter and warned other migrants to avoid the mistakes that he identified in his career. Robert Foster moved to Los Angeles, became a prosperous doctor and treated many of the migrants who found their way to his office. He did well enough to host a reception for his far-flung family and his local friends that was luxurious enough to be labelled the Party of 1970 by the Los Angeles Sentinel (Wilkerson, 2010, 413-30).

It is clear that the fortunes of members of the Great Migration varied greatly, but there were gains to many migrants from moving North. The problem in identifying these gains is that they showed up mostly in the second generation. Recent research has shown that movement to another neighborhood often helps in the long run even if not in the short run. Another large change was the expansion of the minimum wage to occupations which were disproportionately held by Blacks. This move away from racist New Deal policy caused a significant closing of the Black/white income gap (Chetty and Hendron, 2018a, 2018b).

For example, Jacob Lawrence's parents were in the first wave of The Great Migration and they met on the way north. Jacob went to school in Harlem as a teen-ager and was enrolled in an artsand-crafts program after school to keep him busy while his mother worked. He became an artist and painted a sequence of 60 pictures depicting the Great Migration in 1940 when he was 22 years old. The pictures now are divided between the Museum of Modern Art in New York and the Phillips Collection in Washington, DC (Lawrence, 1993).

The transfer of Southern racial housing segregation to the North went largely unnoticed by the white press. White residents moving out to grass and trees did not seem to be conscious that the suburbs were all white. (They also did not seem to notice that women were left out of the growing economy.) Fifty years later, this period is looked back on as the peak of American prosperity and world leadership, forgetting the legacy of slavery that was being recreated in this new world and the subjection of women that was seen as family disruptions in the new suburbs. Part of this movement was subsidized by the growth of the interstate, which increased suburbanization and led to construction employment among whites (Baum-Snow 2007). 
On May 18, 1954, Greensboro, North Carolina, became the first city in the South to announce publicly that it would abide by the Supreme Court's Brown v. Board of Education ruling. "It is unthinkable," remarked School Board Superintendent Benjamin Smith, "that we will try to [override] the laws of the United States." This positive reception for Brown, together with the appointment of an African American to the school board in 1953, convinced numerous white and Black citizens that Greensboro was heading in a progressive direction. Integration in Greensboro occurred rather peacefully compared to the process in Southern states such as Alabama, Arkansas, and Virginia where "massive resistance" was practiced by top officials and throughout the states.

In Virginia, some counties closed their public schools rather than integrate, and many white Christian private schools were founded to accommodate students who used to go to public schools. Even in Greensboro, local resistance to desegregation continued, and in 1969, the federal government found the city was not in compliance with the 1964 Civil Rights Act. Transition to a fully integrated school system did not begin until 1971.

Many Northern cities also had de facto segregation policies, which resulted in a vast gulf in educational resources between Black and white communities. In Harlem, New York, for example, neither a single new school was built since the turn of the century, nor did a single nursery school exist - even as the Second Great Migration was causing overcrowding. Existing schools tended to be dilapidated and staffed with inexperienced teachers. Brown helped stimulate activism among New York City parents like Mae Mallory who, with the support of the NAACP, initiated a successful lawsuit against the city and state on Brown's principles. Mallory and thousands of other parents bolstered the pressure of the lawsuit with a school boycott in 1959. During the boycott, some of the first freedom schools of the period were established. The city responded to the campaign by permitting more transfers to high quality historically white schools. New York's African-American community and Northern desegregation activists generally, now found themselves contending with the problem of white flight.

On December 1, 1955, nine months after a 15-year-old high school student, Claudette Colvin, refused to give up her seat to a white passenger on a public bus in Montgomery, Alabama, and was arrested. Rosa Parks did the same thing and soon became the symbol of the resulting Montgomery Bus Boycott and received national publicity. She later was hailed as the "mother of the civil rights movement" (Thornton, 2014).

Rosa Parks was secretary of the Montgomery NAACP chapter and had recently returned from a meeting at the Highlander Folk School in Tennessee where nonviolence as a strategy was taught by Myles Horton and others. After Parks' arrest, African Americans gathered and organized the Montgomery Bus Boycott to demand a bus system in which passengers would be treated equally. Jo Ann Robinson, a member of the Women's Political Council who had been waiting for the opportunity to boycott the bus system led the organization. Following Rosa Park's arrest, Robinson mimeographed 52,500 leaflets calling for a boycott that were distributed around the city and helped 
gather the attention of civil rights leaders. After the city rejected many of their suggested reforms, the NAACP pushed for full desegregation of public buses. With the support of most of Montgomery's 50,000 African Americans, the boycott lasted for 381 days, until the local ordinance segregating African Americans and whites on public buses was repealed. Ninety percent of African Americans in Montgomery partook in the boycotts, which reduced bus revenue significantly, as they comprised the majority of the riders. In November 1956, the United States Supreme Court upheld a district court ruling in the case of Browder v. Gayle and ordered Montgomery's buses desegregated, ending the boycott.

Local leaders established the Montgomery Improvement Association to focus their efforts, and elected Martin Luther King Jr. as president of this organization. The lengthy protest attracted national attention for him and the city. His eloquent appeals to Christian brotherhood and American idealism created a positive impression on people both inside and outside the South.

After the Freedom Rides, local Black leaders in Mississippi asked SNCC to help register Black voters and to build community organizations that could win a share of political power in the state. Since Mississippi ratified its new constitution in 1890 with provisions such as poll taxes, residency requirements, and literacy tests, it made registration more complicated and stripped Blacks from voter rolls and voting. Violence at the time of elections earlier also had suppressed Black voting.

By the mid-20th century, preventing Blacks from voting had become an essential part of the culture of white supremacy. In June and July 1959, members of the Black community in Fayette County, TN, formed the Fayette County Civic and Welfare League to spur voting. At the time, there were 16,927 Blacks in the county, yet only 17 of them had voted in the previous seven years. Within a year, some 1,400 Blacks had registered, and the white community responded with harsh economic reprisals. Using registration rolls, the White Citizens Council circulated a blacklist of all registered Black voters, allowing banks, local stores, and gas stations to conspire to deny registered Black voters essential services. What's more, sharecropping Blacks who registered to vote were evicted from their homes. Overall, the number of evictions came to 257 families, many of whom were forced to live in a makeshift Tent City for well over a year. Finally, in December 1960, the Justice Department invoked its powers authorized by the Civil Rights Act of 1957 to file a suit against seventy parties accused of violating the civil rights of Black Fayette County citizens. In the following year the first voter registration project in McComb and the surrounding counties in the Southwest corner of the state. Their efforts were met with violent repression from state and local lawmen, the White Citizens' Council, and the Ku Klux Klan. Activists were beaten, there were hundreds of arrests of local citizens, and the voting activist Herbert Lee was murdered.

White opposition to Black voter registration was so intense in Mississippi that Freedom Movement activists concluded that all of the state's civil rights organizations had to unite in a coordinated effort to have any chance of success. In February 1962, representatives of SNCC, CORE, and the 
NAACP formed the Council of Federated Organizations (COFO). SCLC became part of COFO at a subsequent meeting.

In the Spring of 1962, with funds from the Voter Education Project, SNCC/COFO began voter registration organizing in the Mississippi Delta area around Greenwood, and the areas surrounding Hattiesburg, Laurel, and Holly Springs. As in McComb, their efforts were met with fierce opposition-arrests, beatings, shootings, arson, and murder. Registrars used the literacy test to keep Blacks off the voting rolls by creating standards that even highly educated people could not meet. In addition, employers fired Blacks who tried to register, and landlords evicted them from their rental homes. Despite these actions, over the following years, the Black voter registration campaign spread across the state.

SNCC, CORE, and SCLC began similar voter registration campaigns - with similar responses in Louisiana, Alabama, southwest Georgia, and South Carolina. By 1963, voter registration campaigns in the South were as integral to the Freedom Movement as desegregation efforts. After the passage of the Civil Rights Act of 1964, protecting and facilitating voter registration despite state barriers became the main effort of the movement. It resulted in the passage of the Voting Rights Act of 1965, which had provisions to enforce the constitutional right to vote for all citizens.

A. Philip Randolph, chair of the Brotherhood of Sleeping Car Conductors, and Bayard Rustin were the chief planners of a march on Washington, which they proposed in 1963. The Kennedy administration initially opposed the march out of concern it would negatively affect the drive for passage of civil rights legislation. However, Randolph and King were firm that the march would proceed. With the march going forward, the Kennedys decided it was important to work to ensure its success. Concerned about the turnout, President Kennedy enlisted the aid of white church leaders and Walter Reuther, president of the UAW, to help mobilize white supporters for the march.

The march took place on August 28, 1963. The planning of the 1963 march was a collaborative effort of all of the major civil rights organizations, the more progressive wing of the labor movement, and other liberal organizations. The march's major focus was on passage of the civil rights law that the Kennedy administration had proposed after the upheavals in Birmingham. The march was a success, although not without controversy. An estimated 200,000 to 300,000 demonstrators gathered in front of the Lincoln Memorial, where King delivered his famous "I Have a Dream" speech.

While many speakers applauded the Kennedy administration for the efforts it had made toward obtaining new, more effective civil rights legislation protecting the right to vote and outlawing segregation, John Lewis of SNCC took the administration to task for not doing more to protect southern Blacks and civil rights workers under attack in the Deep South. 
After the march, King and other civil rights leaders met with President Kennedy at the White House. While the Kennedy administration appeared sincerely committed to passing the bill, it was not clear that it had enough votes in Congress to do so. However, when President Kennedy was assassinated on November 22, 1963, the new President Lyndon Johnson decided to use his influence in Congress to bring about much of Kennedy's legislative agenda.

Segregation was encouraged by the solid Democratic South before President Johnson's Great Society led them to switch parties. The Democratic South excluded Blacks from the force of federal legislation by limiting the laws to manufacturing workers, excluding farm workers and domestic maids. They insisted that the administration of laws be placed in the hands of local officials who were antagonistic toward Black progress. And they refused to allow Congress to insert anti-discriminatory language into any social welfare programs, including local hospitals and school lunches (Katznelson, 2005, 22-23).

The 1960s opened with the Beatles invading the white world and Freedom Riders trying to escape the traditional Black world. The progress of TV increased the awareness of both new ventures among Americans of all sorts. President Kennedy seemed more interested in the former than the latter, but pressure from his brother and others forced him to pay attention to the latter. His attempts to help the Freedom Riders and other Southern protestors were cut short by his 1963 assassination. Johnson asked Congress to declare unconditional war on poverty. Congress passed the Economic Opportunity Act (EOA) that created the Office of Economic Opportunity (OEO) in 1964. It followed with bills that transformed American schools, created Medicare and Medicaid, and expanded many ongoing federal efforts to relieve poverty. Despite the many contributions Johnson made while president, his reputation has suffered partly because he expanded the Vietnam War and partly because he did not leave a political legacy to the Democratic Party.

The way the EOA and OEO were set up shows the latter problem. The funds were distributed to states, but the distribution within states was left to local administration. Poverty rates and the share of non-whites were the primary determinants of where the funds were used. Rather than employing these funds to help local politicians, OEO funds were used to circumvent the local elite. The OEO apparently wanted to supplant the old leadership to avoid the legacy of Jim Crow that they were presumed to honor. But this attempt to provide new leadership did not lead to political support. It was a serious attempt to alleviate poverty, but it did not stimulate political change that would maintain the new and increased support (Bailey and Duquette, 2014).

President Johnson also steered through Congress what he called the Kennedy bill to restore the voting rights of Blacks. The Civil Rights Act of 1965 restored the voting rights of Black citizens of the United States that had been guaranteed in the $15^{\text {th }}$ Amendment. As we have seen, the Supreme Court nullified the $14^{\text {th }}$ and $15^{\text {th }}$ Amendments in the course of the 1880 s as a sort of gravestone for Reconstruction that had died in 1876. Johnson restored the model of chapter 3 that showed Blacks wanting the vote to improve their schools. 
These domestic events were accompanied by foreign events that would come back to haunt civil rights at home. Indeed, the involvement of the United States in Second World War made them susceptible to attacks that their ideals about democracy and protection of rights was a myth. One view from the Kennedy Administration tied them together by linking support for the Civil Rights Act from conservative congressional representatives to Johnson's continued support for the Vietnam War.

There were about 75,000 American troops in Vietnam in mid-1965. There were few American casualties and the war seemed destined for resolution in Saigon. Then, after some military reversals, General Westmoreland in Vietnam requested an open-ended American commitment to the war, turning it into an American war. Robert McNamara later called the cable a "bombshell." Johnson adopted Westmoreland's program in substance if not detail in order to preserve his Congressional support for his Great Society programs, including the 1965 Voting Rights Act. He believed he was in a honeymoon with Congress after Kennedy's death, and he could not abandon Vietnam and preserve his domestic program (Bator, 2007).

Johnson's Great Society programs were an attempt to broaden President Roosevelt's New Deal during the Depression. Southern Congressmen had excluded Blacks from much of the New Deal and GI Bill, and Johnson tried to broaden the scope of federal government assistance. Blacks were ruled out of Social Security by the exclusion of agriculture from its coverage, and Black GIs were restricted to Black colleges that were too poor to build dorms for them. Johnson took account of the Great Migration that was transforming the oppression of Blacks from a regional to a national problem. He tried to provide health care for Blacks by including them in Medicare and Medicaid.

One of the effects of Johnson's Great Society program was to convince southern voters that the Democrats were no longer looking after their interests. A succession of Democratic presidents from Truman to Johnson had acted to promote the rights of Black Americans and destroy Jim Crow laws. Southern voters turned from being Democrats to Republicans (Kuziemko and Washington, 2018).

The late 1960s were chaotic. There were civil disturbances and race riots in many cities around the country: Harlem in 1964, Watts and Chicago in 1965 and Newark, Detroit and other cities in 1967. Martin Luther King and Robert F. Kennedy were assassinated in 1968. Crime suddenly had risen all over. People were scared, and President Johnson appointed a National Advisory Commission on Civil Disorders, known as the Kerner Commission, in 1967 to help understand what was going on. The Kerner Commission's Report concluded: "What white Americans have never fully understood-but which the Negro can never forget - is that white society is deeply implicated in the ghetto. White institutions created it, white institutions maintain it, and white society condones it (Kerner Commission, 1968, Chapter 16, Summary; Harris and Elkins, 1986, 19)." 
The report concluded that policies should move toward a single integrated society, but the government rushed the report into publication for political reasons, and the report largely vanished as concern over the Vietnam War rose. President Johnson signed the Safe Streets Act after all these murders and urban disturbances as political views shifted from social welfare to law enforcement. The War on Poverty always had an ambiguous meaning as wars are inherently violent, and this aspect of Johnson's efforts rose to primacy as conservatives acquired more influence. The act created the Law Enforcement Assistance Administration that expanded punitive supervision and control in low-income urban areas throughout the 1970s. Conservatives increasingly saw Johnson's extension of civil rights as the cause of crime and lawlessness, reversing the direction stated in the Kerner Commission Report (Hinton, 2016).

The urban disturbances of the late 1960s also scared many people and set the stage for militarization of the police. The Warren Supreme Court was on both sides of this issue. It helped defendants against the police in its 1966 Miranda decision and encouraged the police in approving stop and frisk policies by the police in 1968. While the assignation of Martin Luther King set off riots in Los Angeles, the police started the riots in Chicago during the Democratic Convention later in 1968. Nixon expanded the Law Enforcement Assistance Administration in the 1970s to support local police and SWAT forces. The first time SWAT forces were used was to ambush the Black Panthers while they slept in 1969 (Balco, 2014, chapter 4).

Increasingly opposed by conservative whites, Johnson's civil rights laws were observed in the breach for a few decades and then nullified by the Supreme Court. More than a century after Blacks were freed from slavery and declared citizens of the United States, they still had only limited voting rights. They did however achieve some educational gains.

Unlike Reconstruction, Black education started and expanded during the Civil Rights Movement had a lasting impact. School desegregation significantly increased educational attainment among Blacks exposed to desegregation during their school-age years, with impacts found on the likelihood of graduating from high school, completed years of schooling, attending college, graduating with a 4-year college degree, and college quality. Nonparametric event-study estimates and sibling-difference estimates indicate that school desegregation and the accompanied increases in school quality also resulted in significant improvements in adult labor market and health status outcomes, and reductions in both the annual incidence of adult poverty and incarceration for Blacks. The significant long-run impacts of school desegregation found for Blacks with parallel findings across a broad set of socioeconomic outcomes and health status indicators of well-being, with no corresponding negative impacts found for whites, is striking (Johnson, 2011).

Twenty percent of Black men had graduated from high school by 1970, compared with seven percent in 1950. And four percent of Black men had graduated from college by 1970, compared with less than three percent in 1950. The Black college graduates in 1950 were from poor southern colleges; they were largely from predominantly white colleges by 1970. Aspiring Black students 
were in demand during the 1960s in both desegregated southern colleges in and northern white colleges (Freeman, 1976, 41-52).

This educational progress has been analyzed, starting from Head Start and going through high school, providing the Black students for colleges, and separately for Black college graduates. Head Start was started in 1964 as part of Johnson's War on Poverty. It has been renewed and improved several times since, not without some hazards. When George W. Bush renewed funding of Head Start in 2007, he used code words that showed his opposition, "I am pleased that this bill addresses several longstanding Administration priorities, such as increased competition among Head Start providers, improved coordination of early childhood delivery systems, and stronger educational performance standards." "Competition" was code for looking for private charter Head Start programs. "Coordination" was code for reducing the multidimensional focus in very young children, and "performance standards" meant tests for short-run impacts rather than the important long-run impact. President Bush was trying to privatize the predominantly Black educational system. President Obama reversed this direction in subsequent years, looking to evaluate Head Start teachers on their relationships with the students rather than focusing on multiple-choice tests Bush, 2007; Head Start, 2015[TVMC]).

Rucker Johnson adopted a unique research strategy to identify changes in Black and white students during integration that took place at different times in different places during the decades after Brown v. Board of Education. He started from the Panel Study of Income Dynamics (PSID) that followed 18,000 Americans starting in 1968 and tracked life outcomes of cohorts from birth to adulthood across several generations. He merged these annual observations with educational data on desegregation and Head Start in every school district across the country, focusing on three cures to inequality: integration, school funding, and high-quality preschool investments.

In order to change from observation to testing the effects of desegregation, Rucker Johnson needed to have a control group akin to those used in proving new medicines. Each participant in the PSID had too many family and social indicators to differentiate treatment and control groups. Johnson turned to school districts and assumed that the distribution of students was unrelated to the politics of desegregation orders. He found 868 judicial orders enacted between 1954 and 1980 and created parallel universes for affected and segregated school districts. This enabled him to see the effects of integration by contrasting students in these two kinds of districts, treated by integration and controls (Johnson, 2019, 10-11, 54-57).

Rucker Johnson chronicled six effects of school desegregation on student outcomes on Blacks and whites. Court-ordered desegregation had no effect on white students at all. It had cumulative effects on Black students that increased with the number of years students continued as students after desegregation orders. Black students had improved educational attainment, that is, years of education, and higher likelihood of graduating from high school. They had reduced probability of being incarcerated and higher wages. They had reduced probability of poverty as adults and better 
health. In each case, they were included more in the white economy as a result of desegregationwithout in any way diminishing the effect of education on their white cohorts.

Using a similar approach to study school financing, Johnson examined court-ordered school financing reforms and found similar effects, identified here as poor rather than Black students. For low-income students, an increase in per-pupil spending had cumulative effects like those of integration on years of completed education, higher earnings and less poverty. A 25 percent increase in per-pupil spending throughout a student's school years eliminated the attainment gaps between poor and rich children.

Head Start had similar effects that changed all of these outcomes in favorable directions. More important, well-funded Head Start and well-funded schools had larger effects on poor students than the sum of the effects of the two increases separately. Other economists have found varied effects of Head Start because the long-term effects of Head Start are affected strongly by the schooling that follows. Future policy changes need to see Head Start and K-12 education as joint activities that need to be integrated to affect students. They are not alternatives nor competitors for funding, but rather parts of the educational process to educate poor students so that they can use their talents productively in later life. President Johnson started before neuroscience developed to show the effect of early education, but his creation of Head Start was prescient and showed how important early education is to changing lives (Johnson, 2019).

Black college graduates after 1950 were more often from white northern universities than before, although they were still a small minority of American Blacks. They were in high demand as a result of the Civil Rights Movement, and these Black graduates went into good jobs. They were a Black elite, in Richard Freeman's apt title. This highly educated elite was fully absorbed into the white economy, as a few Black individuals had been previously. This was a big step, but limited by the inadequacies of early education.

Only around sixty percent of nonwhite college graduates were professionals or managers in 1950, compared with three-quarters of all graduates. The nonwhite graduates caught up to the 1950 level of all graduates, which had increased to 80 percent by 1970 . Nonwhites gained absolutely and relative to whites. Most of the gain was in management, a new field for Blacks, and it continued into the 1970s. The relative incomes of the Black elite also rose at the same time. Black professional incomes rose from 58 to 72 percent of white professionals, and Black managers rose from half to two-thirds of white managers (Freeman, 1976, tables 5, 11).

These gains did not arise from magic. They came from the increase in northern college attendance. The Black students not only gained from a better education than their predecessors in southern colleges, they also gained access to information about the job market that awaited them. Southern Black colleges were still part of the backward South, and they lacked the ties to northern firms that northern colleges had. Stimulated by the Ford Foundation, organizations were formed and funds 
were raised for placement programs. It is hard to disentangle the effect of these efforts from straight economic opportunities, but interviews suggested that they were a significant influence. The careers of the new Black college graduates were helped by a new labor market in response to economic incentives (Freeman, chapter 3, 57-85).

The federal government under Lyndon Johnson also made discrimination illegal in these markets. The Civil Rights Act of 1964, amended in 1972, and Executive Order 11246 imposed heavy fines and other punishments for discrimination in professional and management hiring. The Civil Rights Act ruled out discrimination by employers, employment agencies and unions. It applied to hiring, firing, compensation and the terms and privileges of employment and union membership. It established the Equal Employment Opportunity Commission (EEOC) to administer the law. The EEOC had a budget of about $\$ 45$ million and brought over 34,000 cases, mostly dealing with southern discrimination. Regression analysis showed that the EEOC had a significant and large effect on Black professional and managerial incomes (Freeman, 1976, 130).

The government also helped Black professionals by hiring them. The federal government hired Blacks as managers, while state and local governments hired them as teachers. The market of teachers shows the interactions between the elite and other Blacks experiencing the integration of schools. School integration meant that fewer Black teachers were needed in integrated schools than had been needed to staff Black schools. But the demand for new Black teachers, predominantly in the north, offset this fall in demand, keeping the total demand for Black teachers high. The demand for Black college professors grew as well, and the wages of Black teachers and professors grew. Freeman, writing in the 1970s, concluded, "If the developments of the 1960s and early 1970 s continue into the future, the decade will mark a major turning point in Black economic history (Freeman, 1976, 215).”

Many African Americans had used their freedom to move north and west during the world wars to escape a failing agriculture and Jim Crow laws, changing racism from a regional problem to a national one. But economic and political changes in the 1970s ended the Great Migration and reduced migrants' gains as the white American economy leapt ahead. When Candidate Richard Nixon said he was adopting a Southern Strategy in 1968, he was signaling that he would continue the Republican tradition of using Jim Crow laws to separate African Americans from the white economy.

The Great Migration ended in 1970 because the jobs that Blacks hoped to find in the North were vanishing. This change can be seen in the original division of activity that was introduced when national income accounting originated in the 1930s. Simon Kuznets grouped economic activity into three groups: agriculture, manufacturing, and services. The industrial revolution led workers to switch from agriculture to manufacturing. They moved into towns to find work, studied at schools and increased their incomes. Starting in the 1970s, economic activity moved from manufacturing to services. The change was subtle because new manufactured objects were involved, but the services - TV, iPhones, Facebook, Google, etc.- - were more prominent than the 
manufactured delivery devices. Jobs in manufacturing declined, and jobs in the new electronic services grew.

These new jobs required a college education. As we have seen, some Blacks completed college and found jobs in these new industries, but most Blacks did not. We will see what happened to them shortly. For now, we observe that the wage premium for college graduates, which had been decreasing earlier in the $20^{\text {th }}$ century, increased dramatically after 1980 . The return from a year of $\mathrm{K}-12$ schooling showed little change after 1980. But the return to a year of college education rose from 0.076 in 1980, to 0.126 in 2000 and to 0.141 in 2017 . The returns to a year of post-college education (graduate and professional) rose from 0.067 in 1980 , to 0.131 in 2000 , and to 0.176 in 2017. The primary reason for this rapid growth in the wages of college graduates was due to a slowing down of college attendance after 1980. It also was accompanied by increased spread of wages within college graduates, suggesting that different kinds of education led to different wages. But the returns to the Black elite were high (Autor, Goldin and Katz, 2020).

Southern Blacks migrating northward had only limited education, and they could not find work in the new economic activities. They found themselves adrift in northern cities and looked around for jobs that did not require much education. Younger migrants also looked for education to qualify themselves for better jobs. Education in northern cities was more available than in the rural south, but the migrants typically did not have access to good schools.

Blacks increasingly lived in cities vacated by whites as suburbia grew, but urban property values fell as Blacks moved in. Blacks running from Southern Jim Crow policies lacked the income and capital of unionized white workers. And an important decision by the Supreme Court in 1974 condemned urban school systems to growing poverty. The case came from Detroit, which had absorbed many Black families seeking work. They were excluded from white neighborhoods by restricted access to mortgages and the opposition of white neighbors. The Detroit school district was two-thirds Black by the 1970s, and the NAACP filed suit against Michigan Governor William Milliken and others, charging direct discrimination against Blacks in the drawing of school districts.

The Supreme Court held in Milliken v. Bradley (418 US 717) that school districts were not obligated to desegregate unless it could be proven that the lines were drawn with racist intent. Historical lines that produced segregated districts were not illegal. In other words, if the population is stable and officials used race to draw school districts, that would be illegal. But if school districts were stable and the population changed-particularly if it changed from white to Black-there was no illegality.

Intent is a familiar concept in criminal law, where it has been used for many, many purposes. The application to public policy, however, is fraught with problems. Public decisions often are made by people interacting in complex political processes. The records of their discussions typically are brief and often bland. It is harder to find intent in a committee's actions than in an individual's 
actions. The Supreme Court used a traditional indicator in a way that accepted cities' policies without inquiring into their causes or effects.

The 1974 Milliken decision made it clear that white flight would successfully separate white suburbanites from their new dark-skinned neighbors. The decision ensured that Black urban communities would lack an adequate fiscal base. The Supreme Court would not combine or otherwise alter existing school districts, and whites fleeing cities for suburbs would be able to separate their children from those of urban Blacks. The decision also mandated poverty conditions for the urban school districts, which became poorer and Blacker over time. The tax base for urban schools decreased as urban factory jobs decreased, and fleeing whites avoided paying for urban schools. The Supreme Court limited school busing across city boundaries and encouraged rising racial segregation between inner cities and suburbs. The result was segregated schools with inadequate resources for urban schools attended by the children of the Great Migration. Separate and unequal, one might say.

Milliken v. Bradley was brought by the NAACP to further the implementation of Brown v. Board of Education. The decision meant that integrated education could be avoided by white flight from cities. Brown v. Board of Education was effectively dead after only twenty years. The 1974 Supreme Court repeated the actions of the 1880s Supreme Court in voiding the first section of the $14^{\text {th }}$ Amendment roughly twenty years after the Amendment was adopted in 1868. Justices Powell and Rehnquist, two years after becoming Supreme Court Justices, made Nixon's Southern Strategy into a national policy.

President Nixon was a pivotal figure in a tumultuous period. He adopted a Southern Strategy for his domestic program as he ran for president in 1968. But he approached the expanding Vietnam War very differently. The Tet Offensive had been painful, and the North Vietnamese wanted to bargain with the South to see if they could share power in Vietnam. Nixon urged the Vietnam government to stall the peace negotiations that President Johnson had started. A recent Nixon biographer commented, "Under federal law, which bans private citizens from undercutting the government by negotiating with foreign powers, Nixon's actions were potentially felonious (Farrell, 2017. 342n)."

The American economy was in turmoil in the late 1960s. The expansion of the Vietnam War under Presidents Johnson and Nixon led to rising prices in the United States and changed the dollar shortage after World War II into a dollar glut. The Nixon Shock in 1971 took the United States off the gold standard and out of the Bretton Woods agreement that supported prosperity and trade in the 1950s, fixed prices temporarily and imposed some tariffs. While Nixon's actions did not formally abolish the existing Bretton Woods system of international financial exchange, the suspension of one of its key components effectively rendered the Bretton Woods system inoperative (Neal, 2015). 
Then the Organization of Petroleum Exporting Countries, OPEC, raised oil prices dramatically in 1973. And various other actions changed inflation to "stagflation." This was a new term in macroeconomics, since economists were used to inflation caused by full employment. The combination of unemployment and inflation required new thinking. President Carter asked his economic advisor not to use the word, recession, in the late 1970s. The advisor called it a banana. We are facing similar conditions in the coronavirus of 2020; we may face a new kind of stagflation, possibly with another cute label.

There were race riots in many cities around the country in the late 1960s in response to the growing Vietnam War. White people were scared, and President Johnson appointed the Kerner Commission, in 1967 to help understand what was going on. The Kerner Commission's Report was rushed into publication for political reasons and soon was drowned out by concern over the Vietnam War. It however crystalized what was going on in a pithy conclusion: "What white Americans have never fully understood-but which the Negro can never forget - is that white society is deeply implicated in the ghetto. White institutions created it, white institutions maintain it, and white society condones it (Kerner Commission, 1968, Summary; Harris and Elkins, 1986, 19)."

Nixon ignored this report, and it was forgotten as he transformed Johnson's War on Poverty into his War on Drugs. His two top policy advisors recalled later how Nixon determined to deal with the urban riots. John Ehrlichman, President Nixon's domestic adviser, revealed later how Nixon hoped to exploit the domestic turmoil: "The Nixon campaign in 1968, and the Nixon White House after that, had two enemies: the antiwar left and Black people. You understand what I'm saying? We knew we couldn't make it illegal to be either against the [Vietnam] war or Black, but by getting the public to associate the hippies with marijuana and Blacks with heroin, and then criminalizing both heavily, we could disrupt those communities. We could arrest their leaders, raid their homes, break up their meetings, and vilify them night after night on the evening news. Did we know we were lying about the drugs? Of course we did (Baum, 2016)."

H. R. Haldeman, Nixon's Chief of Staff, confirmed Nixon's attitude in his diaries. He described views of President Nixon, "P" in the diaries, as follows: "P emphasized that you have to face the fact that the whole problem is really the Blacks. The key is to devise a system that recognizes this while not appearing to. $P$ pointed out that there has never in history been an adequate Black nation, and they are the only race of which this is true. Says Africa is hopeless. The worst there is Liberia, which we built (Haldeman, 1994; Associated Press, 1994)."

President Nixon's position was inconsistent. He prolonged the Vietnam War in 1968. Blacks, along with many whites, rioted against the war and the conscription it entailed. Yet Nixon had no trouble blaming the Blacks for the violence instead of owning it himself. As conservative presidents often do, he diverted attention from his own faults to achieve other aims he had in mind. 
President Nixon replaced President Johnson's War on Poverty with a new War on Drugs. The rate of incarceration in the United States started to rise soon after the Great Migration ended. It had stayed constant near one hundred people per 100,000 residents from 1925 to 1970 and then grew rapidly after 1980. The incarceration rate rose rapidly for the next thirty years, although more slowly after 2000 as shown in Figure 1. The incarceration rate in the European Union, Canada and Mexico stayed near 100 per 100,000 residents, the American rate before 1980. The current American incarceration rate around 600 is the highest in the developed world, beating even Russia's incarceration rate. (Raphael and Stoll, 2013, 5-10; Carson and Anderson, 2016).

Federal laws were expanded in state laws that ranged from three-strike laws to harsh penalties for possession of small amounts of marijuana. The laws also shifted the judicial process from courtrooms to offices where prosecutors put pressure on accused people to plea-bargain. The threat of harsh minimum sentences gave prosecutors the option of reducing the charge to a lesser one if the accused was reluctant to languish in jail - if he or she was unable to make bail and face the possibility of long years in prison. The number of inmates grew primarily from the increase in convictions rather than the length of sentences. "Few people in the criminal justice system are as powerful, or as central to prison growth, as the prosecutor." (Stuntz, 2011, 286; Pfaff, 2017, 127)

The crack epidemic of the 1980s led to policy changes that combined the two movements of the 1970s. The changes originated to reform the judicial process to lower prison terms, promote consistency among courts and encourage alternative sanctions to prison. By the time various bills were combined and transformed into the Sentencing Reform Act of 1984, however, the aim had shifted to become a part of the War on Drugs and the national toughness on crime. A series of laws followed that translated the new, tough approach into detailed sentencing guidelines (Lynch, 2016, Chapter 2).

The Anti-Drug Abuse Act of 1986 was passed after a basketball player died from a drug overdose and Republicans accused Democrats of being soft on crime. Democrats wanted to take credit for an anti-drug program in the November elections, so the bill had to pass Congress by in October. That required action on the House floor in September, and committees had to finish their work before the August recess. Since the idea was born in July, committees had less than a month to develop the ideas, write the bills to carry out those ideas and get comments from the relevant government agencies and the public at large.

The House Judiciary Committee considered a new idea that was "tough on drugs" for the first time four days before the recess began. The idea was to create mandatory minimum sentences in drug cases, which had tremendous political appeal. It was a type of penalty that had been removed from federal law in 1970 after extensive and careful consideration. But no hearings were held on reviving this idea in 1986. No experts on the relevant issues, no judges, no one from the Bureau of Prisons or from any other office in the government provided advice on the idea before it was rushed 
through the committee and into law. After bouncing back and forth between the Democratic House and the Republican Senate as each party jockeyed for political advantage, the Anti-Drug Abuse Act of 1986 passed both houses a few weeks before the November elections (Sterling, 1999).

The Anti-Drug Abuse Act of 1986 mandated a minimum sentence of five years without parole for possession of five grams of crack cocaine, while it mandated the same only for possession of five hundred grams of powder cocaine. This 100:1 disparity clearly criminalized Blacks who favored crack cocaine far more than whites did. Nixon's War on Drugs became firmly integrated into a New Jim Crow. The result was that one of three Black men could expect to spend time in prison by the 1990s (Bonczar, 2003; Alexander, 2010).

The racial disparity between whites and Blacks under the new rules can be seen in the contrast of between this estimate and the estimated one of seventeen white men who could expect incarceration. Despite the racial disparity of incarceration, poor whites outnumber them in prisons, echoing the violence against poor whites in the 1840s and the first Gilded Age. As in the depressed 1840s, poor whites suffer along with Blacks (Lynch, 2016, 26; Temin, 2018).

The disparity dropped to 18:1 in 2010, when the illegal possession of crack cocaine was increased to 28 grams ( 1 ounce) by the Fair Sentencing Act of that year. The larger disparity had continued for a quarter century, supported by the backlash from the Civil Rights Movement, Nixon's Southern Strategy, and the belief that Black prisoners were inherently criminal-not ordinary people who had done criminal things (Raphael and Stoll, 2013, 115-20).

The Anti-Drug Abuse Act of 1986 also allowed prosecutors to seek a doubling of the mandatory minimum sentences if the defendant had a prior conviction. Another law passed in 1988 allowed prosecutors to ask for life imprisonment without parole for defendants who had two or more prior drug convictions. The War on Drugs became a New Jim Crow (Alexander, 2010; Bonczar and Beck, 1997; Lynch, 2016, 26).

Congress ordered the Secretary of Defense in 1987 to notify local police each year about the availability of surplus equipment. The military had been giving some surplus equipment to local police forces before, and this new policy sharply increased the flow of military equipment to the police. Police officers then had to be trained to operate their new accessions, which altered their views from caretaking to conquering (Balco, 2014, 158).

Congress determined the shape of another crime bill a decade later. President Clinton proposed another crime bill to allay fears of as the crime wave of the 1980s reached its peak with a bill that would put 100,000 more police on the streets and expand prisons. These punitive measures were offset by a ban on assault weapons and a variety of social programs aimed at crime prevention and social intervention. Clinton's centrist approach gave solace to advocates of both punishment and rehabilitation. 
The bill seemed on the way to passage when racial conflict upset it. One of the social programs in the bill provided for midnight basketball to occupy errant youths and reduce the danger they posed on the nighttime street. Midnight basketball rapidly became associated with helping Black youths and a code word for racial benefits. It raised deeply entrenched images and ideas associating crime with young African-American men that heightened the threat of crime and raised serious questions about preventative programs. The social programs were stripped from the bill, and it passed containing only the punitive parts. Clinton signed it, an action he later regretted (Wheelock and Hartmann, 2007; Raphael and Stoll, 2013).

The disparity in the minimum sentences for crack and powder cocaine lasted until 2010, when the illegal possession of crack cocaine was increased to 28 grams (1 ounce) by the Fair Sentencing Act of that year, decreasing the racial ratio from 100:1 to 28:1. The larger disparity had continued for a quarter century, supported by the backlash from the Civil Rights Movement in Nixon's Southern Strategy, and the belief that Black prisoners were inherently criminal-not ordinary people who had done criminal things (Raphael and Stoll, 2013, 115-20).

Todd Clear, a prominent criminologist, argued that the growth of mass incarceration disrupted families, social networks and other forms of social support. After a certain point, the collateral effects of high rates of incarceration contributed to more - not less - crime. The resulting crime fueled a public call for ever-tougher responses to crime. The politics of race and justice sustained an ever-growing policy base that guaranteed new supplies of penal subjects in a self-sustaining manner (Clear, 2007, 175).

The effect of all these laws and convictions can be seen in figure 2, which shows the incarceration rate for Blacks and whites in 2010. The upper line for Black incarceration rates was above the rate for whites, but much further above for poor families. This clear difference shows that race was dominant, even though income also was important in the aftermath of growth of a Black elite described in the last chapter. College educated Black men were far safer from drug convictions than the working-class men (Chetty and Hendren, 2020a, b).

However, even well-off Blacks faced anger from whites that seem to transcend class. Trayvon Martin was shot by a white man when he went out to buy something for his mother at the corner store in 2012 Florida. His killer was found innocent, recalling the treatment of lynching a century earlier. Ahmaud Arbery was shot while jogging for exercise in 2020 Georgia. His killers are currently awaiting trial. Killings and incarceration are different, but they come from the same racist impulses (Alvarez and Buckley, 2013; Fausset and Rojas, 2020).

As mass incarceration grew, it put pressure on state governments. About ninety percent of prisoners are in state prisons. And the fiscal weight of these prisoners put pressure on state budgets which reduced education expenditures. States universities lost funds whenever there was a fiscal crisis, and primary and secondary schools lost funds more smoothly. Mass incarceration thus 
lowered economic growth in two ways. Prisoners were not educated while in prison, although we do hear of occasional prison schools. More importantly, the funds for the schooling of all the other children has been reduced (Mitchell and Leachman, 2014; Temin, 2018).

The effects of incarceration on the individuals involved can be seen in figure 3. This model distinguishes three human modes. Customary behavior is simply doing today what you did yesterday and possibly earlier times as well. Instrumental behavior, beloved by economists, is to further aims that the individual has. Economists often label this mode as rational. Command behavior is doing what you are told by whatever authority is commanding you.

When in prison, you adhere to command behavior unless you are eager for penalties from the prison administration. Schooling, almost by definition, teaches instrumental behavior. These modes of behavior are opposed to each other. Prisoners are not supposed to choose instrumental actions; they are to follow orders. And prison guards are not prepared to honor choices that prisoners might want to make to improve their welfare, date of release, or any other aim. Prison schooling therefore is an oxymoron.

The changes described so far - the end of the Great Migration, the start of mass incarceration, and reduced educational expenditures - were roughly coincident in the 1970s. This suggests that they might have been related. Recent research suggests that in fact they were. It is hard to separate cause and effect in simultaneous changes, and economists use what they call identifying strategies to make the distinction. The strategy here is to assume that members of the Great Migration tended to join African American communities that were already established in the North. More migrants meant more prisoners in the War on Drugs. Examining local variations in the rate of Black settlement in the North, we can identify mass incarceration as a cause of reduced school spending.

The story can be summarized as follows. Black migration increased white suburbanization. The introduction of automobiles and new highways increased whites to move to the suburbs, and almost three whites left cities for each added Black resident. The Supreme Court determined in Milliken, 1974, that the Black cities would be poor. President Reagan and Bush reduced federal funding for cities in addition. As urban manufacturing work disappeared, Black and white urban working-class communities deteriorated. Drug use increased, and mass incarceration gathered steam. The disappearance of good urban jobs set this process off, and that is the third of the changes that occurred around 1970 and quite possibly the ultimate cause of these interrelated changes (Wilson, 1996; Boustan, 2010; Derenoncourt, 2019).

Nixon converted federal programs into block grants to states in order to give states more choice in how to spend the money, calling his move a New Federalism. Reagan then reversed fifty years of American domestic policy by cutting back federal grants to local and state governments that the federal government used to help poor people. Public service jobs and job training were reduced sharply, and the share of federal funding for large cities fell from 22 percent to 6 percent of their 
budgets. The decline of both private and public sources of employment in inner cities greatly reduced employment opportunities for white and Black urban residents alike (Temin, 2017).

President Reagan continued Nixon's Southern Strategy by initiating his presidential campaign in Philadelphia, MS. Why in such a small town? Because every Southerner and sympathizer knew that three civil rights workers, Chaney, Goodman and Schwerner, were murdered in Philadelphia during the 1964 Freedom Summer while attempting to register Blacks to vote. Reagan did not need to say a word for this effective claim to sympathize with white supremacists to be effective. He supported states' rights and condemned the Federal Government as an enemy of the (white) people.

The long-run effects of the New Federalism can be seen in the 2015 crisis of lead pollution in the public water supply to Flint, Michigan. Flint had been an auto manufacturing center, but employment in the auto industry declined soon after Blacks came to Michigan for good jobs during the Great Migration. Blacks arrived to find reduced employment, and the city of Flint was unable to pay its bills as manufacturing continued to decline through the 1990s. Republican Governor Rick Snyder was elected in 2011 and supported a controversial law that allowed him to appoint emergency managers of cities in financial trouble. He put Flint into receivership and appointed an emergency manager in 2012. There were four different managers in the next three years, an arrangement that was not likely to yield comprehensive plans.

An emergency manager took Flint off the Detroit water system to save money in April 2014. He decided to take Flint's water from a local river instead. The immediate result was brown water pouring out of the faucets in peoples' homes, and lots of complaints from residents about the new water supply. Detroit offered to reconnect Flint to its water system in January 2015, and to forego a substantial connection fee. A different emergency manager refused.

The complaints became sharper when high levels of lead were found in Flint's water in February and March 2015. This was known in the governor's office, but no action was taken. In September of that year, several doctors made a public statement that many Flint children had elevated levels of lead in their blood. Soon after the doctors' news conference and a year and a half after the switch to river water, the state began to act. Flint was reconnected to the Detroit water system in October.

The residents of Flint by then had high levels of lead in their blood and pipes into their homes that were damaged by the river water and needed help. The state government brought fresh bottled water to Flint for emergency help, but that was all it did. State funds for reconstruction were blocked by political objections, and federal emergency funds were blocked as well. The residents of Flint were unable to move, locked in by home ownership and other constraints, and the needed investment in Flint's water pipes is being made very slowly. (Bosman, 2017; Smith, Bosman and Davey, 2019; Davenport, 2019). 
Conservative rich people considered Johnson's Great Society to be harmful to the unregulated competition that they desired. That explains why the funds needed to restore damaged water pipes in Flint and provide help for children whose brains were damaged by bad water have been so hard to find. Betsy DeVos, President Trump's Secretary of Education, is a Michigan resident, and her family has a great deal of political interest in the state.

Returning to events around 1970, varied forces starting then resulted in a change in the demand for specific jobs that created an hourglass job profile, splitting the American labor market into a low-wage part and a higher-wage part. Low-wage workers are laborers and service workers. Highly paid workers are professionals and managers. A college education is needed to get hired into the top group. Lower-paying jobs barely allow workers to maintain the lifestyle they grew up expecting. They do not provide enough income for people to save for retirement, which seems farther away than many current needs. And as these changes progressed, jobs disappeared in the low-wage sector, harming potential workers more.

The changing face of jobs often seems to be the result of technological change, but technology is only part of the story. Several causes can be distinguished, and they can be divided into domestic and international. All of them are results of governmental decisions. Government, primarily military, spending, promoted advances in technology and electronics. The growing interest in and deregulation of finance shaped firms and industries. Globalization was accelerated by policies opening international capital markets, promoting American foreign investment and American economic influence.

The development of computers increasingly substituted for labor in routine tasks, that is, tasks that can be accomplished by following explicit rules. These factory jobs were the basis of unions in the twentieth century, and unions lost members and influence as these trends continued. The Great Migration ended in the economic confusion of the 1970s and left the new Northern urban residents scrambling for good jobs as the nature of work changed (Autor, 2019).

The percentage of the labor force in unions declined from 39 percent in 1954 to 10 percent today. Unions lost effectiveness as well. In the 1970s, strikes involved more than 950,000 workers in every year; in the 1990s, by contrast, strikes never involved even half a million workers, despite a larger labor force. Many more strikes were broken, with employees losing their jobs. Unions had diminishing political influence within the Democratic Party and increasing Republican Party dominance. Explanations of these changes focus respectively on demographic changes, the role of the union itself, the state, especially the legal system, globalization and neoliberalism, and the employer anti-union offensive (Clawson and Clawson, 1999).

As jobs and unions disappeared, wages stagnated for both whites and Blacks. This wage stagnation came from diverse causes and has lasted for at least fifty years. It comes from both technical and organizational changes in business and from both domestic and foreign developments. Unions disappeared as jobs vanished, and the loss of labor bargaining power broke the connection between 
increasing labor productivity and wages. This new pattern differs dramatically from the shared benefit of economic growth before 1970 (Temin, 2017).

The changes have changed the distribution of income. Labor's share fell while capital's share grew. The fall of labor's share of GDP in the United States and many other countries in recent decades is well documented but its causes remain uncertain. Existing empirical assessments typically rely on industry or macro data, obscuring heterogeneity among business firms. Since globalization and technological changes pushed sales towards the most productive firms in each industry, product market concentration rose as superstar firms, which have high markups and a low labor share of value-added, dominated. It was not simply trade and technology, but also the policy decision not to constrain the new large and even monopoly firms that led workers to lose out in the post-industrial economy (Autor, et al., 2020; Lazonick, et al, forthcoming).

Some Black men and women who had been educated in the postwar prosperity were absorbed into this new and changing economic structure on almost the same terms as white workers with similar training. This new Black elite is a durable result of the Civil Rights Movement. But less educated Blacks did not do so well. They were the last to be hired in many factories and therefore the first to be fired as foreign competition grew. The upward mobility that they had shared with their more educated white peers turned to downward mobility as the economy and the political environment changed (Freeman, 1976).

Educated Blacks and whites were able to educate their children for good jobs in the new economy but fired factory workers could not. Affirmative action disappeared under President Reagan. They also could not buy houses or new cars or move into better neighborhoods. Working class Blacks fell behind whites both in salaries earned and wealth accumulated. And even those Blacks who graduated college wanted to avoid discriminatory experiences at work and to help other Blacks. They chose to work in non-profits, governments and civil rights law (Lazonick, et al., forthcoming).

Japan and then China increased their exports, imitating the export-led growth path of England and Germany a hundred years earlier, and American jobs were hurt. As computers took over repetitive tasks, more jobs were lost. And as finance expanded in the late 1970s, companies were encouraged to specialize in their core activities, that is, the activities that they were known and patronized for. This would increase their value on the stock market, and outside firms and services could be hired to do menial jobs. The same computers that reduced factory jobs also made it easier to create instructions for service jobs and to monitor them.

The company supervisor was replaced by a contract with a separate company that monitored workers. For example, most hotel employees used to work for the hotels they worked in. Today, over 80 percent of a hotel's employees are hired and supervised by a separate management 
company. They no longer have a path to advancement within the hotel company, they typically also lack vacations and pension plans, and their economic mobility has decreased greatly (Weil, 2014).

The shift from paying wages to hiring subcontractors was a momentous change in the place of workers in a business enterprise. When workers were wage earners, there was a social component to their work. Workers saw themselves as a group and being a member of a stable group fostered morale. Most successful firms gain from the identification of workers with the firm and the extra care and effort that produces. When workers are hired instead by a competitive service company, they have no identification with the parent firm. They have low morale and will not exert extra effort for the parent company's benefit. Intrusive monitoring replaces morale, and antagonism replaces cooperation. This change particularly affected Blacks who had missed the opportunity to get an education in the prosperous years (Temin, 2017).

More important, Blacks who attempted to upgrade their skills became victims of for-profit education. The increasing returns to skill created a market where firms created educational programs of high cost and little value, and where they preyed upon Black workers looking to increase their skill in the market. These schools left Blacks with high amounts of debt and few marketable skills at a time when more modest investments in skills from lower cost options would have had a higher return. Even when trying to adapt to the new economy, Blacks found themselves victimized again (Cottom, 2017).

The share of national income of the richest members of the economy increased as the share of income captured by workers with unchanging wages fell. The United States and other Englishspeaking countries have the most unequal incomes in the world. And American inequality was increased further by tax cuts for the rich under Reagan and Trump. A recent book summarizes the results: "The wealthy have seen their taxes rolled back to levels last seen in the 1910s, when the government was only a quarter of the size it is today. It is as if a century of fiscal history has been erased (Saez and Zucman, 2019, xi).”

The 2008 financial crisis proved to be one more pin in the coffin of racial equality. While Blacks had made significant gains in income and homeownership from the 1950s to the end of the twentieth century, the housing market collapse reversed the vast majority of that progress. In some American cities, Blacks have average wealth of less than $\$ 100$. Nationally, a white household who did not finish high school has more wealth on average than a Black household with a college education. The policies which historically excluded Blacks from wealth building cannot be solved by education or labor market policies which concentrate on income. It is the product of a historical legacy. 
The 2008 financial crisis resulted in the election of the United States first Black president, Barack Obama. This election was the most exciting result of the Black elite that had grown in the Civil Rights Movement. It was one thing to have Black doctors, lawyers and businessmen; it is quite another to have a Black president. This shows that it is bad education, not innate inferiority, that condemns most Black people to poverty in America. Education is not simply formal schooling, but also growing up in a stable environment where students can absorb and learn.

President Obama was a beacon of success to part of the American population. But his election also was a sign of imminent danger to the racist part of the population. The population of the country is polarized along several dimensions, but the racial division dominates the discussion of political fortunes. This Janus-like result of Obama's administration needs to be kept in mind as we analyze resulting events. He is married to Michelle Obama, who was a descendant of American slaves. She helped him in his campaign and was accused by the racists of being an angry Black woman-revealing both faces of educated Black people in the United States (Obama, M., 2018).

Obama had an ideal upbringing in Hawaii where there were mixed races and few Blacks. He went to Harvard Law School and was editor of the Harvard Law Review while there. Then he went to Chicago and worked with poor Black communities before entering politics. He served in the House of Representatives and then the Senate. He gave a stunning speech at the 2014 Democratic convention and was selected to be a candidate in 2008. He might have been elected in any case, but he was helped by his Republican opponent's apparent ignorance of what was happening in the financial crisis as the election approached in the fall of 2008. Race fell into the background as the economy tanked to resurface quickly after the financial crisis (Obama, B., 2007).

Obama wanted to alleviate the suffering that followed the crisis, but he had only a limited command of economics. He therefore followed the advice of his economics teachers and staff members. The two most important advisers were Robert Rubin, Secretary of the Treasury under President Clinton, and Lawrence Summers, a senior U.S. Treasury Department official throughout President Clinton's administration, who President Obama appointed director of the National Economic Council. Rubin had been the head of Goldman Sachs before entering the government, and he was Summers' boss during President Clinton's administration.

The flavor of their advice can be seen in negotiations that preceded Obama's inauguration. Christina Romer, the prospective head of Obama's Council of Economic Advisors, showed the group how three alternative sizes of fiscal expansion should stimulate the economy: "What happens if we do $\$ 600, \$ 800$, and $\$ 1.2$ billion of stimulus? If you want to keep unemployment below 8 percent, you do $\$ 800$. But if you want to get it down quickly to below 7 percent you need to do something really big like $\$ 1.2$ billion." Summers deleted the $\$ 1.2$ billion from the memo to the president-elect. His argument was that he did not think the new administration could get that 
much through Congress, and it would not be good for the president ever to be seen as losing (Hundt, 2019, 132-33).

Unemployment went up to 10 percent in 2009 , and $\$ 1.2$ billion fiscal policy stimulus would have been better. Even if the president did not get all he wanted, he would have been better off starting high and ending nearer $\$ 800$ billion. In fact, the president lost by not asking for the larger amount. The administration thought about a second stimulus package in the summer of 2009, but the Republicans would not consider more spending. One chance was enough. Was Summers being conservative or too cautious to engage Republicans with a larger stimulus?

After the economic crisis calmed down a bit, President Obama started to negotiate with Republicans about his plan for what would become the Affordable Care Act. He did not realize how opposed the Republicans are toward poor people, and spent several months dickering with them. The reform act passed in March 2010. It was dubbed Obamacare by the Republicans, and Obama was flattered. He did not realize that the nickname would remind the poor that this was a Black man's plan, and it has become the expression used most often for the organization that administers the Affordable Care Act.

Obamacare was a great success. It reduced the uninsured by half and did not allow discrimination based on previous illnesses. Together with the Health Care and Education Reconciliation Act of 2010 amendment, it was the U.S. healthcare system's most significant regulatory overhaul and expansion of coverage since the passage of Medicare and Medicaid in 1965. The act largely retained the existing structure of Medicare, Medicaid and the employer market, but individual markets were radically overhauled. Insurers were made to accept all applicants without charging based on pre-existing conditions or demographic status (except age). To combat the resultant adverse selection, the act mandated that individuals buy insurance (or pay a fine/tax) and that insurers cover a list of "essential health benefits".

Obamacare faced strong political opposition before and after enactment, with calls for repeal and legal challenges. In National Federation of Independent Business v. Sebelius, the Supreme Court ruled that states could choose not to participate in Obamacare's Medicaid expansion, although it upheld the law as a whole. Republican states typically did not expand Medicaid even though the federal government would pay almost all the added cost. The map of states that did not expand Medicaid looks like the 1904 election and the Confederacy, although some Midwest cities are included too. Polls initially found that a plurality of Americans opposed the act, although its individual provisions were generally more popular and the law gained majority support by 2017 .

The law caused a significant reduction in the number and percentage of people without health insurance. The percentage of people without health insurance fell from 16 percent in 2010 to 9 percent from January to June 2016. Approximately 12 million people were covered by the exchanges (10 million of whom received subsidies) and 11 million added to Medicaid. Another 
million were covered by Obamacare's "Basic Health Program," for a total of 24 million. The uninsured rate dropped in every congressional district in the United States from 2013 to 2015. (Barry-Jester, 2016).

As in the 1880s, the Supreme Court stepped in soon after the 2008 Financial Crisis to promote corporations' progress in several landmark decisions. Early in 2010, the Supreme Court decided Citizens United, 558 U.S. 310, ruling that the government could not restrict independent political expenditures by nonprofit companies because money spent by corporations was the same as speech. This decision greatly eased the flow of campaign contributions from rich individuals and large corporations. The opinion defined corruption as bribery only when it had an explicit quid pro $q u o$, which means the explicit exchange of something of value for a specific and identifiable government action. This is a much narrower definition of bribes than the Supreme Court held in prior cases where a variety of gifts were ruled illegal, although it was introduced earlier in Buckley v. Valeo, 424 U.S. 1 (1976). As the opinion in Citizens United expressed the new, narrow standard, "Independent expenditures, including those made by corporations, do not give rise to corruption or the appearance of corruption (Teachout, 2014, 7, 232).”

This decision extended the Supreme Court's favoritism toward corporations that started in the $1880 \mathrm{~s}$ when they turned the $14^{\text {th }}$ amendment around to apply to corporations instead of freedmen. This and following decisions would replay the Supreme Court's vision from the 1880s that corporations were people and deserved much more consideration than African Americans (Winkler, 2018, chapter 10).

Citizens United, decided in January, changed the political landscape. The Democrats were discouraged after the fight for the Affordable Care Act and the slow recovery from the financial crisis of 2008, and they did not understand how quickly the Republicans would act on the Supreme Court's decision. The Koch brothers and their little heralded-at that time-organizations were quick to seize the opportunity. Reasoning that their money would have more impact in smaller markets, they poured money into state races for governors and representatives in the 2010 midterm elections. Democrats were slow to take advantage of this opportunity. They were neither disciplined nor under centralized control, and they had far fewer liquid resources at their disposal than the Kochtopus (Mayer, 2016; Page, Seawrite and Lacombe, 2019).

Republicans then put into operation its REDMAP, a plan to redistrict in favor of Republicans. Gerrymandering is a traditional American practice, but REDMAP was the first set of state actions orchestrated in a national effort. The first step was to jam voters likely to favor your opponents into a few throwaway districts where the other side could win lopsided victories, a strategy known as "packing." The second step was to arrange other boundaries to win close victories, "cracking" opposition groups into many districts. As a result of lopsided political spending, Republicans 
emerged from the 2010 election with just shy of thirty Republican state governors and almost as many Republican-controlled state legislatures.

As a result of REDMAP, Democrats received 1.4 million more votes than Republicans for the House of Representatives in 2012, yet Republicans won control of the House by a 234 to 201 margin. Democrats would have had to win the popular vote by 7 percentage points to take control of the House districts (assuming that votes shifted by a similar percentage across all districts), a margin that happens in only about one-third of Congressional elections. The ability of Democratic voters to change the leadership of the House of Representatives is very limited; plutocrats - the one percent - sharply hamper their access.

The role of money in politics has grown since then, although readers may recall that money mattered in the 1896 presidential election. Candidates are ranked by how much money they have raised, and scholars have found a linear relation between money and votes. The new technology just described shows how money was transformed into votes through various electronic channels (Ferguson, et al. 2019).

The Voting Rights Act of 1965 incorporated provisions to deal with the legacy of Jim Crow laws in the South. The Supreme Court ruled that its most effective provision was unconstitutional in Shelby County v. Holder (570 US 529) in 2013, just as the Supreme Court had eviscerated the $14^{\text {th }}$ Amendment in the 1880s. The Voting Rights Act required selected states, mostly in the South, to preclear proposed voting arrangements with the federal government. In other words, the federal government would decide whether voting arrangements would violate the Voting Rights Act before they went into effect. The Supreme Court ruled this provision was unconstitutional because the coverage formula was based on data over forty years old, making it no longer responsive to current needs and therefore an impermissible burden on the constitutional principles of federalism and equal sovereignty of the states (Overton, 2006).

Despite the Supreme Court's assertion that all states are alike, the states that had been listed in the original bill immediately rushed to impose voting restrictions that otherwise would not have passed preclearance. While it seems clear that these restrictions are racially motivated, they can no longer be phrased in that way. The difficulties of voting therefore affect low-wage whites and Blacks. Between growing inequality and continuing race prejudice, democracy seems to be on a downward trajectory.

The Supreme Court more recently accelerated this decline in another case, Rucho v. Common Cause (588 U.S. _ 2019), by ruling that states could not be sued in federal courts for partisan gerrymandering of congressional districts. The court said it still had jurisdiction over racial gerrymandering, but it failed to draw any connections between partisan and racial gerrymandering. Since modern Republicans look increasingly like Southern Democrats in the original Gilded Age, 
future partisan gerrymanders will shrink the effects of Black votes. This is not as violent as Jim Crow laws a century ago, but it may be as effective in reducing Black votes.

By delegating voting right to states, the Supreme Court replicated the practice of late $19^{\text {th }}$ and early $20^{\text {th }}$ century Southern senators. Southerners used this practice repeatedly to reduce the impact of federal programs on the Jim Crow practices of the South. The Great Migration changed a Southern problem to a national one, and the Supreme Court has now signed on to the modern opposition to Reconstruction. 


\section{Figure 1}

State and Federal Prison Inmates per 100,000 U.S.

Residents, 1925 to 2009

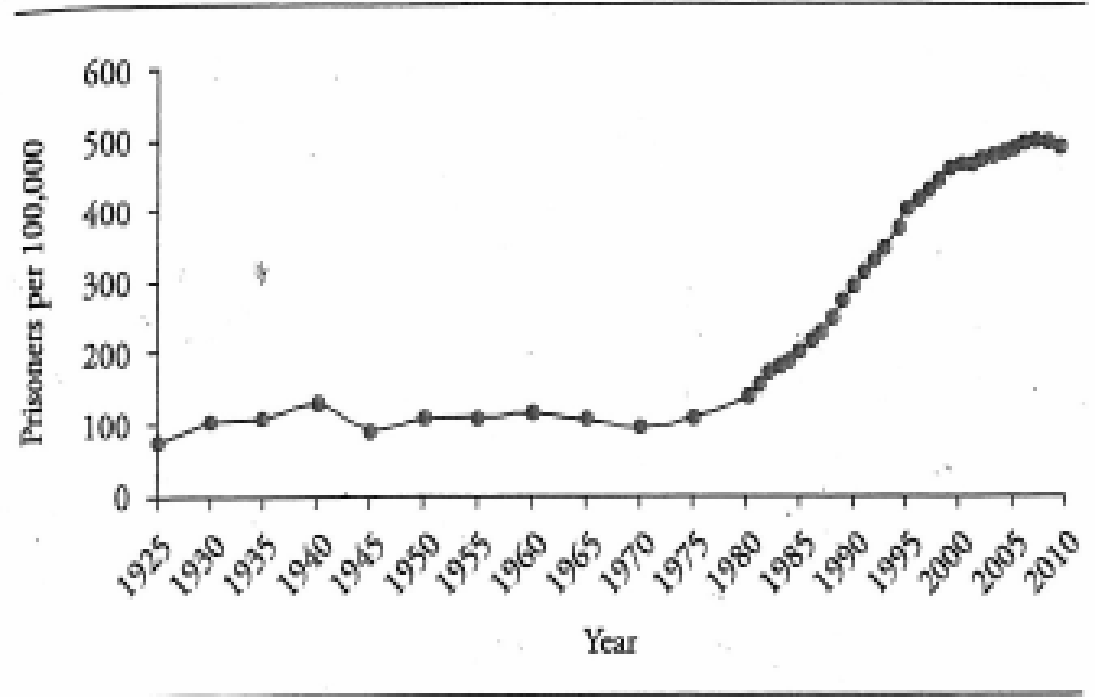

Sowne: Auchors' compilation based on Bureau of Justice Statistics, National Prisoner Seatistic (various years).

Source: Raphael, Steven, and Michael A. Stoll. 2013, 5. 
Figure 2

Incarceration rates by income and race, 2010

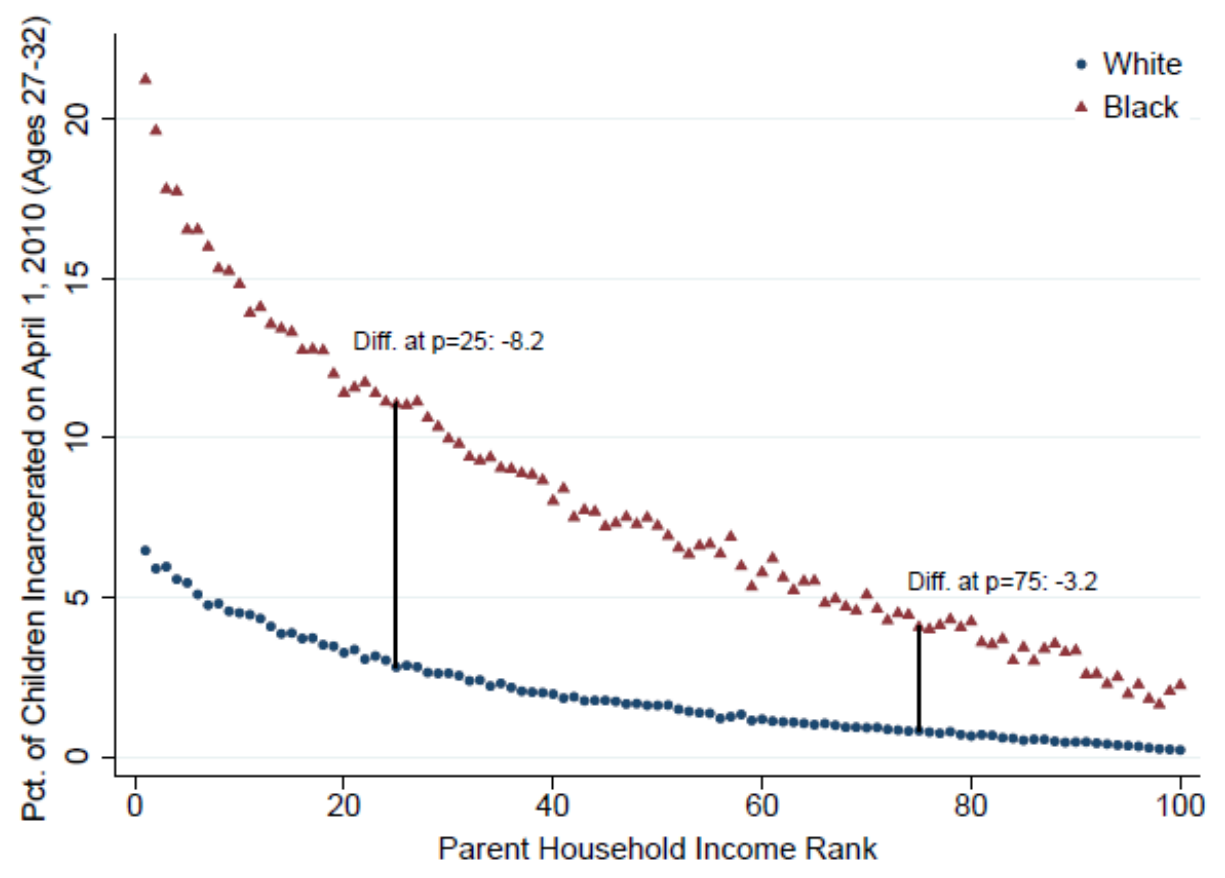

Source: Chetty, 2018a. 
Figure 3

Modes of Behavior

Figure 2

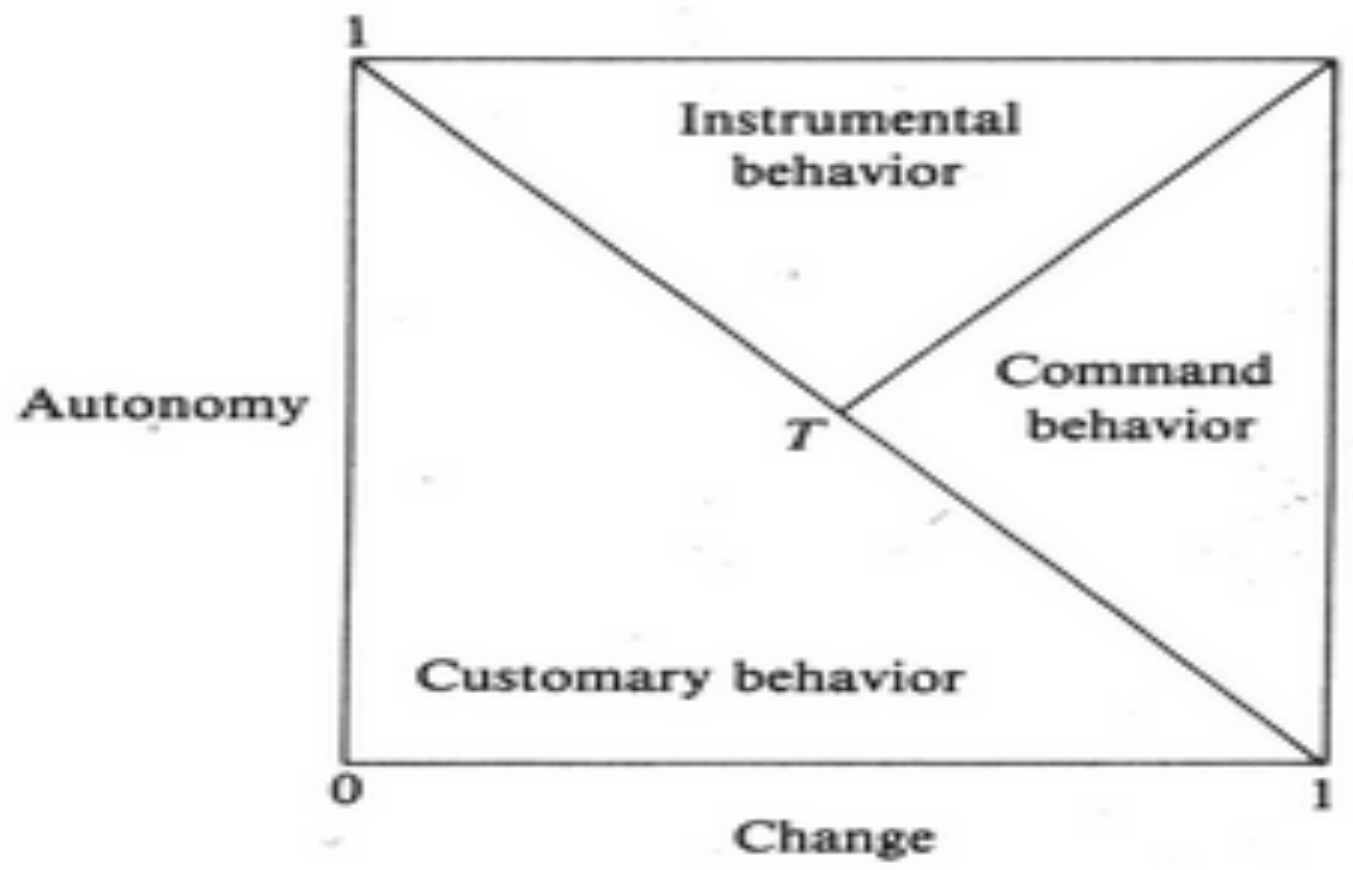

Sources: Temin, 1980. 


\section{Figure 4}

\section{Tax rates for Billionaires}

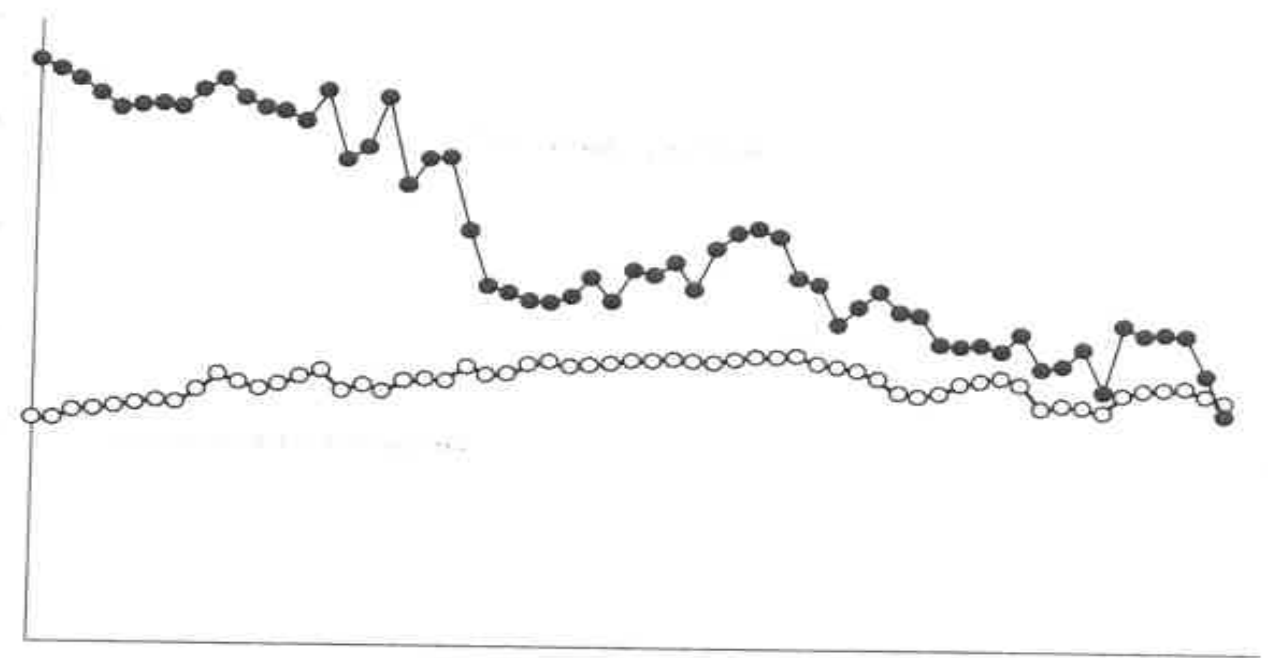

Source, Saez and Zucman, 2019, 23. The solid dots show the tax rate for the top 400 taxpayers. The empty dots show the tax rate on the lowest 50 percent of taxpayers. The graph runs from 1960 to 2020. The op, solid dot, curve starts around 60 percent, and the lower, empty dots, starts and stay near 20 percent. 


\section{References}

Abramoviz, Alan, 2018. The Great Alignment: Race, Party Transformation, and the Role of Donald Trump. New Haven: Yale University Press.

Alexander, Lewis, and Janice Eberly, "Investment Hollowing Out," IMF Economic Review 66 (1), 2018. Available at SSRN: https://ssrn.com/abstract=3162101 or http://dx.doi.org/10.1057/s41308-017-0044-2

Alvarez, Lizette, and Cara Buckley, 2013. "Zimmerman Is Acquitted in Killing of Trayvon Martin," New York Times, July 14.

Anderson, Carol. 2016. White Rage: The Unspoken Truth of Our Racial Divide (New York: Bloomsbury.

Associated Press, 1994, "Haldeman Diary Shows Nixon Was Wary of Blacks and Jews.” New York Times, May 18.

Autor, David, 2019. "Work of the Past, Work of the Future," AEA Papers and Proceedings, 109, 1-32 (May).

Autor, David, Claudia Goldin and Lawrence F. Katz, 2020. "The Race between Education and Technology Revisited," AEA Papers and Proceedings, 110, 347-51.

Autor, David, et al., 2020. "The Fall of the Labor Share and the Rise of Superstar Firms," Quarterly Journal of Economics, 135(2), 711-83.May.

Bailey, Martha J., Nicolas J. Duquette, 2014, "How Johnson Fought the War on Poverty: The Economics and Politics of Funding at the Office of Economic Opportunity," Journal of Economic History, 74 (2), 351-88. June.

Barry-Jester, Anna Maria; Ben, Casselman (2016). "Obamacare Has Increased Insurance Coverage Everywhere". FiveThirtyEight, September 22.

Baum, Dan. 2016. “Legalize It All: How to Win the War on Drugs.” Harper's Magazine, April.

Bonczar, Thomas P. 2003. "Prevalence of Imprisonment in the U. S. Population, 1974-2001." U.S. Department of Justice, Bureau of Justice Statistics, August, NCJ 197976.

Bosman, Julie, 2017. "Michigan Allots \$87 Million to Replace Flint's Tainted Water Pipes," New York Times, March 27.

Boustan, Leah Platt, 2010. "Was Postwar Suburbanization 'White Flight'? Evidence from the Black Migration.” Quarterly Journal of Economics, 124 (1), 417-43 (February). 
Boustan, Leah Platt, 2017. Competition in the Promised Land: Black Migrants in Northern Cities and Labor Markets. Princeton: Princeton University Press.

Carey, Kevin, 2020. "The 'Public' in Public College Could Be Endangered," New York Times, May 5.

Carson, E. Ann, and Elizabeth Anderson. 2016. "Prisoners in 2015.” U.S. Department of Justice, Bureau of Justice Statistics, December, NCJ 250229.

Chetty, Raj, and Nathaniel Hendren (2018a). "The Impacts of Neighborhoods on Intergenerational Mobility I: Childhood Exposure Effects.” Quarterly Journal of Economics 133(3): 1107-1162.

Chetty, Raj, and Nathaniel Hendren (2018b). "The Impacts of Neighborhoods on Intergenerational Mobility II: County-Level Estimates.” Quarterly Journal of Economics 133(3): 1163-1228.

Clawson, Dan, and Mary Ann Clawson, 1999. "What Has Happened to the US Labor Movement? Union Decline and Renewal." Annual Review of Sociology, 25: 95-119.

Clear, Todd R. 2007. Imprisoning Communities: How Mass Incarceration Makes Disadvantaged Neighborhoods Worse. New York: Oxford University Press.

Corrado, Carol A., Charles R. Hulten and Daniel Sichel, "Intangible Capital and U.S. Economic Growth." Review of Income and Wealth, 55 (3): 661-85, 2009.

Cottom, Tressie M., 2017. Lower Ed: The Troubling Rise in For-Profit Colleges in the New Economy.

Davenport, Coral (2019). "New E.P.A. Lead Standards Would Slow Replacement of Dangerous Pipes," New York Times, October 10.

Delpit, Lisa, 2012. “Multiplication is for White People” Raising Expectations for Other People's Children. New York: New Press.

Derenoncourt, Ellora (2019). "Can You Move to Opportunity? Evidence from the Great Migration.” Job Market Paper, Harvard University, January 25.

Drucker, Jesse. "The Tax-Break Bonanza Inside the Economic Rescue Package.” New York Times, April 24, 2020.

Fandos, Nicholas, and Julian E. Barnes, 2020. "Republican-Led Review Backs Intelligence Findings on Russian Interference." New York Times, April 21. 
Farrell, John A, 2017. Richard Nixon: The Life.

Fausset, Richard, and Rick Rojas, 2020. "Where Ahmaud Arbery Ran, Neighbors Cast Wary Eyes,” New York Times, May 16.

Federal Reserve, Board of Governors, 2020. Report on the Economic Well-Being of U.S. Households in 2019, Featuring Supplemental Data from April 2020. Washington, DC. May.

Ferguson, Thomas, P. Jorgensen, and J. Chen, 2019. "How Money Drives US Congressional Elections: Linear Models of Money and Outcomes," Structural Change and Economic Dynamics, in press, https://www.sciencedirect.com/science/article/abs/pii/S0954349X19302012

Fields, Karen E., and Barbara J. Fields, 2012. Racecraft: The Soul of Inequality in American Life. New York: Verso.

Flitter, Emily “'Banking While Black’: How Cashing a Check Can Be a Minefield.” New York Times, June 18, 2020.

Freeman, Richard B. (1976). Black Elite: the New Market for Highly Educated Black Americans New York: McGraw-Hill.

Guthrie, Woody, ND, Copyright Woody Guthrie Publications, Inc. (BMI).

Haldeman, H. R., 1994. The Haldeman Diaries: Inside the Nixon White House. New York: G. P. Putnam's Sons.

Hinton, Elizabeth, 2016. From the War on Poverty to the War on Crime: The Making of Mass Incarceration in America. Cambridge, MA: Harvard University Press.

Hundt, Reed. 2019. A Crisis Wasted: Barack Obama's Defining Decisions. New York: RosettaBooks.

Johnson, Rucker C. 2011. "Long-run Impacts of School Desegregation and School Quality on Adult Attainments,” NBER wp 16664.

Keefe, Patrick Radden. "How Mark Burnett Resurrected Donald Trump as an Icon of American Success," New Yorker, January 7.2019.

Kuziemko, Ilyana, and Ebonya Washington, 2018. "Why Did Democrats Lose the South? Bringing New Data to and Old Debate," American Economic Review, 108 (10), 2830-67. 
Lazonick, William, Philip Moss, and Joshua Weitz. 2020. Fifty Years After: Black Employment in the United States Under the Equal Employment Opportunity Commission. Manuscript.

Lynch, Mona. 2016. Hard Bargains: The Coercive Power of Drug Laws in Federal Court. New York: Russell Sage Foundation.

Maheshwari, Sapna, and Vanessa Friedman, "The Pandemic Helped Topple Two Retailers. So Did Private Equity.” New York Times, May 14, 2020.

Mitchell, Michael, and Michael Leachman, 2014. "Changing Priorities: State Criminal Justice Reforms and Investments in Education." Washington, DC: Center on Budget and Policy Priorities, October 28.

Nordhaus, William D. 2006, "Principles of National Accounting for Nonmarket Accounts," in Dale Jorgenson, J. Steven Landefeld, and William D. Nordhaus (eds), A New Architecture of the U.S. National Accounts. Chicago: University of Chicago Press, 143160 .

Obama, Barack. 2007. Dreams from My Father: A Story of Race and Inheritance. New York: Random House.

Obama, Michelle. 2018. Becoming. New York: Crown.

Pfaff, John F. 2017. Locked In: The True Causes of Mass Incarceration-and How to Achieve Real Reform. New York, Basic Books.

Raphael, Steven, and Michael A. Stoll. 2013. Why Are So Many Americans in Prison? New York: Russell Sage Foundation.

Sanger, David E., and Choe Sang-Hun. 2020. "Two Years after Trump-Kim Meeting, Little to Show for Personal Diplomacy,” New York Times, June 12.

Smith, Mitch, Julie Bosman and Monica Davey (2019). "Flint's Water Crisis Started 5 Years Ago. It's Not Over.” New York Times, April 25.

Solow, Robert M., "Thomas Piketty Is Right: Everything you need to know about 'Capital in the Twenty-First Century." New Republic, April 29, 2014.

Temin, Peter. 1980. "Modes of Behavior," Journal of Economic Behavior and Organization, June, pp. 175-195.

Temin, Peter. 2017. The Vanishing Middle Class: Prejudice and Power in a Dual Economy. Cambridge: MIT Press. 
Temin, Peter. 2018. "The Political Economy of Mass Incarceration: An Analytical Model," International Journal of Political Economy 9(4), 1-13 (September).

Temin, Peter. 2019. “Taxes and Industrial Structure,” Business History 61(7), 1144-57.

Temin, Peter. 2020. "Finance and Intangibles in Economic Growth: Eating the Family Cow," International Journal of Political Economy 49 (1), 1-24 (Spring, 2020).

Thornton, J. Miles III, "Challenge and Response in the Montgomery Bus Boycott of 1955-56," Alabama Review, 67 (1), 40-112.

US Department of Labor, Bureau of Labor Statistics, "Employment by Major Industry Sector," 2017. Available at https://www.bls.gov/emp/tables/employment-by-major-industrysector.htm

U.S. Senate, 2020. "Report of the Select Committee of the Senate of the United States Senate on Russian Active Measures Campaigns and Interference in the 2016 Election, volume 4." U. S. Senate, 116th Congress, First Session. Report 116-XX.

Weil, David N. (2014). The Fissured Workplace: Why Work Became So Bad for So Many and What Can Be Done to Improve It Cambridge: Harvard University Press.

Western, Bruce, 2018. Homeward: Life in the Year After Prison. New York: Russel Sage Foundation.

Wilson, William Julius (1996). When Work Disappears: The World of the New Urban Poor New York: Knopf.

Zimmerman, Jonathan, 2020. "What is College Worth?" New York Review of Books, 67 (11), July 2 . 